\title{
The influence of extracts and fractions from matoa leaves (Pometia pinnata) on angiotensin I levels
}

\author{
Ika Purwidyaningrum, Jason Merari Peranginangin, Iyem Sahira \\ Department of Pharmacology, Faculty of Pharmacy, Setia Budi University, Indonesia
}

Keywords
Angiotensin I levels
Ethanol extract
Fraction
Induced angiotensin II
Pometia pinnata
Correspondence
Ika Purwidyaningrum
Department of Pharmacology
Faculty of Pharmacy
Setia Budi University
Indonesia
ika_pur@setiabudi.ac.id

\section{Keywords}

Angiotensin I levels

Fraction

Induced angiotensin II

Pometia pinnata

\section{Correspondence}

lka Purwidyaningrum

Faculty of Pharmacy

Indonesia

ika_pur@setiabudi.ac.id

\begin{abstract}
Introduction: The matoa plant (Pometia pinnata) leaves can be used to treat hypertension. Matoa leaves are thought to have antihypertensive activity because they contain flavonoids. These flavonoids can reduce blood pressure that is modulated by the renin-angiotensin-aldosterone system (RAAS). It is suspected that matoa leaves have antihypertensive activity as they contain quercetin which is a compound that is presumed to be an angiotensin-converting enzyme (ACE) inhibitor. Aims: This study aims to determine which extracts and fractions from matoa leaves are able to decrease angiotensin I levels. Methods: The extraction was done by maceration with $96 \%$ ethanol solvent and fractionated by a liquid method using an n-hexane fraction solvent, an ethyl acetate fraction, and a water fraction. In this study, 21 male Wistar rats were used as test animals and divided into seven groups: Group I was the normal control, group II was the negative control (CMC-Na $1 \%$ ), group III was the positive control (Irbesartan), group IV was given matoa leaf extract with 60 $\mathrm{mg} / 200 \mathrm{~g}$ body weight ratio, Group V was given $2.34 \mathrm{mg} / \mathrm{g}$ fraction of $\mathrm{n}$-hexane, Group VI was given ethyl acetate fraction $9.54 \mathrm{mg} / 200 \mathrm{~g}$ ethyl acetate fraction, and Group VII was given water fraction $7.98 \mathrm{mg} / 200 \mathrm{~g}$ water fraction. The data obtained was analysed using the Shapiro-Wilk test, the Levene test, and analysis of variance (ANOVA). Results: The results showed that the angiotensin I levels induced by angiotensin II were more significant $(p<0,05)$ than those in the normal and negative groups. The ethyl acetate fraction showed a $23.6 \%$ decrease in angiotensin I level, which was close to the $24.8 \%$ decrease in the positive group. The extract from the matoa leaves showed a $17.2 \%$ decrease in angiotensin I levels which were close to the $20 \%$ decrease in the positive group.
\end{abstract}

\section{Introduction}

Hypertension is a cardiovascular disease that affects $34.1 \%$ of the population, based on data from the Indonesian Ministry of Health in 2018. The prevalence of hypertension in Indonesia in 2004 was around 13.4$14.6 \%$, and in 2008 it increased to $16-18 \%$ (Riskesda, 2018). In people aged 18 and over, its prevalence was around $31.7 \%$ in 2007, 32.5\% in 2012 and then decreased by $5.9 \%$ in 2013 (World Health Organization, 2012). Hypertension is a condition where the systolic pressure is equal to or higher than $140 \mathrm{mmHg}$, and the diastolic pressure or diastolic blood pressure is more than $90 \mathrm{mmHg}$ (Kumar et al., 2014).

Matoa leaves contain quercetin-3-O-rhamnoside and kaemferol-3-O-rhamnoside (Suedee, Tewtrakul \& Panichayupakaranant, 2013). These compounds are thought to be responsible for ACE inhibition in matoa leaves. The mechanisms that occur in ACE inhibitors can be used as a reference for the inhibitory mechanisms that occur in plant compounds. It is possible that the matoa leaves may be able to act as a hypertension drug (Suedee, Tewtrakul \& Panichayupakaranant, 2013).

Extracts and fractions taken from matoa leaves have antihypertensive activity with an effective dose of $150 \mathrm{mg} / \mathrm{kg}$ body weight (bw) (Purwidyaningrum, Sukandar \& Fidrianny, 2017). In another study, an extract dosage of $300 \mathrm{mg}$ was able to reduce blood pressure, and the best fraction of $30 \mathrm{mg}$ ethyl acetate fraction induced by angiotensin II was able to reduce systolic, diastolic and mean blood pressure, as well as decrease the heart rate of male Wistar rats (Elisa, 2019). The classification of hypertension drugs is divided based on the mechanism by which they work, 
including diuretics, sympatholytic drugs, and vasodilators that inhibit angiotensin action and production (Dipiro et al., 2017). Angiotensin receptor blockers (ARBs) work by preventing angiotensin II from binding to its receptors (AT1), which causes aldosterone elimination and vasoconstriction. This is then responsible for natriuresis and diuresis, which leads to a decrease in blood pressure (Kumar et al., 2014).

The aim of this research was to determine which matoa leaf extract and fraction (Pometia pinnata) can reduce angiotensin I level in angiotensin II-induced rats.

\section{Materials and method}

To begin with, $500 \mathrm{~g}$ of matoa leaf powder was weighed and then put into a maceration vessel. Following this, $96 \%$ of ethanol was added using a 1:10 ratio (500 g of powder: five litres of ethanol). The matoa leaf powder was soaked in 3.75 parts ( $375 \mathrm{~L}$ ) of $96 \%$ ethanol solvent before being covered and stored at room temperature for five days. It was protected from direct sunlight and shaken three times a day. After five days, the solution was filtered using a flannel cloth, and the maceration vessel was rinsed using the remaining 1.25 parts $(125 \mathrm{~L})$ of $96 \%$ ethanol solvent. It was then filtered again with the added solvent, using a flannel cloth and filter paper. The maceration results were then collected, and the waste was separated (Park et al., 2014). These results were concentrated using a rotary evaporator at a temperature of $40^{\circ} \mathrm{C}$ to obtain a thick extract. The following formula was used in order to calculate the percentage yield.

Fractionation was carried out using the liquid-liquid extraction method. $15 \mathrm{~g}$ of thick ethanol matoa leaf extract was dissolved in $96 \%$ ethanol solvent until mixed. The water and $n$-hexane solvent (1:1) were then added through separated funnels, and the solution was shaken and left standing. The $\mathrm{n}$-hexane fraction was the filtrate at the top, and the water fraction was the filtrate at the bottom. The $n$-hexane fraction was separated, and the water fraction was collected. The resulting solution was concentrated using a rotary evaporator at a temperature of $50^{\circ} \mathrm{C}$. This treatment was repeated three times.

The animal subjects used in this study were white male Wistar rats. The rats were left to acclimatise to their surrounding environment for one week, and then they were weighed. In this study, 21 rats were used, and they were classified into seven test groups, with each test group consisting of three rats. The grouping of the test animals occurred as follows:
Group I was the normal control, group II was the negative control (CMC-Na 1\%), group III was the positive control (Irbesartan), group IV was given matoa leaf extract with $60 \mathrm{mg} / 200 \mathrm{~g}$ body weight ratio, Group $\mathrm{V}$ was given $2.34 \mathrm{mg} / \mathrm{g}$ fraction of $\mathrm{n}$-hexane, Group $\mathrm{VI}$ was given ethyl acetate fraction $9.54 \mathrm{mg} / 200 \mathrm{~g}$ ethyl acetate fraction, and Group VII was given water fraction $7.98 \mathrm{mg} / 200 \mathrm{~g}$ water fraction.

Plasma was taken and added to ethylenediaminetetraacetic acid (EDTA), which acted as an anticoagulant and was then centrifuged for 15 minutes. After this, the angiotensin I levels were measured using an enzyme-linked immunosorbent assay (ELISA) cusabio kit using the indirect ELISA technique.

The differences in each group before and after treatment were analysed by means of a correction test. Statistical analysis was performed using one-way analysis of variance (ANOVA) followed by Tukey's posthoc for parametric tests.

Where $A c$ is the absorbance of the control and As is the absorbance of the sample.

The $\mathrm{IC}_{50}$ calculation was obtained from the linear regression equation after calculating the percentage of inhibition of $\alpha$-amylase enzyme activity of the test material with a concentration range of $2.5 \mathrm{mg} / \mathrm{ml}, 5$ $\mathrm{mg} / \mathrm{ml}, 7.5 \mathrm{mg} / \mathrm{ml}$, and $10 \mathrm{mg} / \mathrm{mL}$. To compare treatments, analysis of variance (ANOVA) was used, and $p<0.05$ was considered as statistically significant, alongside the Tukey Post-Hoc Test significance and 95\% confidence interval. Linear regression measured the median inhibitory concentration $\left(\mathrm{IC}_{50}\right)$ to determine the inhibitory activities of $\alpha$-amylase. IBM SPSS statistic version 22 was used for statistical analysis.

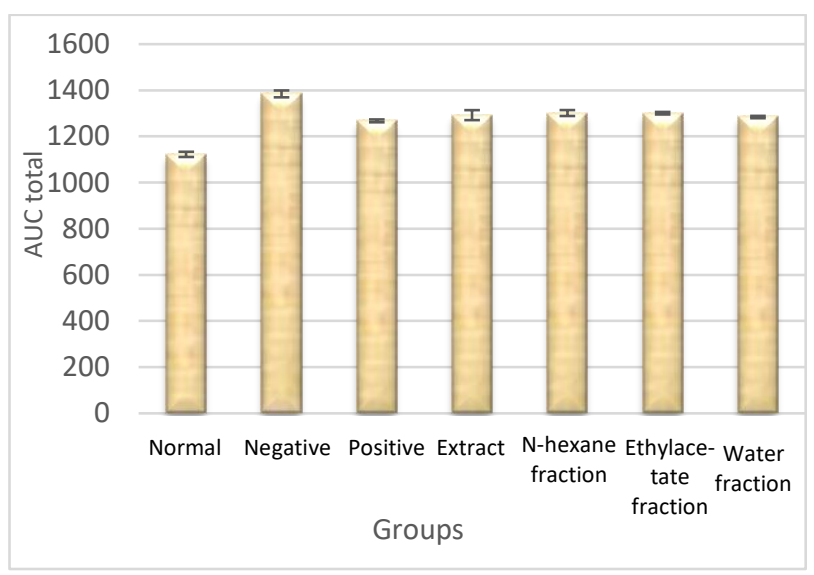

Figure 1: Total of AUC 
Table I: The average angiotensin I level

\begin{tabular}{|c|c|c|c|c|c|c|}
\hline \multirow[t]{2}{*}{ Groups } & \multicolumn{4}{|c|}{ Angiotensin I level (pg/ml) } & \multirow[b]{2}{*}{ AUC } & \multirow[b]{2}{*}{ \% RAA1L } \\
\hline & $T_{0}$ & $T_{1}$ & $T_{2}$ & $T_{3}$ & & \\
\hline Normal & $65.96 \pm 0.0$ & $66.33 \pm 0.1$ & $64.83 \pm 2.6$ & $66.86 \pm 0.2$ & $1122.35 \pm 11.2^{*}$ & 0 \\
\hline Negative & $66.19 \pm 0.0$ & $82.93 \pm 2.2$ & $81.06 \pm 1.1$ & $82.87 \pm 0.2$ & $1384.46 \pm 14.8^{*}$ & 0 \\
\hline Positive & $66.05 \pm 0.1$ & $81.96 \pm 0.6$ & $68.37 \pm 0.1$ & $68.04 \pm 0.1$ & $1267.57 \pm 6.2^{*}$ & 8.44 \\
\hline Extract & $65.89 \pm 0.1$ & $80.70 \pm 1.5$ & $70.18 \pm 0.6$ & $75.75 \pm 2.4$ & $1292.39 \pm 21.7^{*}$ & 6.65 \\
\hline $\begin{array}{l}n \text {-hexane } \\
\text { fraction }\end{array}$ & $66.19 \pm 0.1$ & $80.70 \pm 1.7$ & $74.04 \pm 0.0$ & $73.31 \pm 0.0$ & $1301.55 \pm 12.8^{*}$ & 5.99 \\
\hline $\begin{array}{l}\text { ethyl acetate } \\
\text { fraction }\end{array}$ & $66.07 \pm 0.1$ & $80.78 \pm 0.7$ & $73.92 \pm 0.0$ & $73.09 \pm 0.1$ & $1300.75 \pm 5.5^{*}$ & 6.05 \\
\hline $\begin{array}{l}\text { Water } \\
\text { fraction }\end{array}$ & $65.91 \pm 0.1$ & $81.06 \pm 0.7$ & $69.27 \pm 0.4$ & $73.72 \pm 0.0$ & $1284.12 \pm 5.1^{*}$ & 7.25 \\
\hline
\end{tabular}

RAA1L = Reduce Activity Angiotensin 1 Level; *significant difference to negative control $<0,05$

\section{Results and discussion}

The results obtained in Table I indicate an increase in angiotensin I level after angiotensin II (T1) induction and a decrease after T1 and T2 treatment. Measurements of angiotensin I levels were carried out before therapy (TO), 14 days after the angiotensin I induction period (T1), during the seven days of therapy (T2) and during the seven days following the therapy period (T3) for a total of 28 days of treatment. The area under curve (AUC) is the concentration of test preparation in blood plasma at different time intervals. The AUC in this study (Table I) was the total AUC of the average reduction in angiotensin I level over time intervals of T1 (day 14), T2 (day 21), and T3 (day 28).

The positive group, extract group, n-hexane fraction group, ethyl acetate fraction group, and water fraction group were significantly different from both the normal and negative groups. Giving matoa leaf fractions and extracts to male Wistar rats induced with angiotensin II could reduce their angiotensin I levels. The water fraction $(7.98 \mathrm{mg} / 200 \mathrm{~g})$ and the positive control (Irbesartan) both similarly reduced angiotensin I levels.

The percentage reduction of angiotensin I levels in the treatment group was thought to be due to the chemical contents of the matoa leaves, namely flavonoids (quercetin) and triterpenoids/saponins. Quercetin can affect the renin-angiotensin-aldosterone system (RAAS), so it is thought to reduce both angiotensin I levels and hypertension symptoms in the rats that were induced with angiotensin II (Larson, Symons \& Jalili, 2010). The use of $96 \%$ ethanol solvent is presumed to attract all the compounds from the matoa leaf extract. Ethanol is a very effective polar and non-polar solvent that can dissolve compounds, such as flavonoids, triterpenoids, and saponins.

The ethyl acetate fraction group showed a $23.6 \%$ decrease in angiotensin I level, which was close to the $24.8 \%$ decrease in the positive group. The matoa leaf extract group showed a decrease in $17.2 \%$ angiotensin I levels, which was close to the $20.2 \%$ decrease in the positive group.

\section{Conclusion}

Giving matoa leaves or leaf extracts to male Wistar rats induced with angiotensin II can reduce their angiotensin I levels. The water fraction ( $7.98 \mathrm{mg} / 200 \mathrm{~g}$ ) reduced angiotensin I levels which was the same result that was produced by the positive control (Irbesartan).

\section{Acknowledgements}

The authors would like to thank the DIKTI, who have funded this research all the way to its completion, and would also like to thank the LPPM and the Setia Budi University for allowing its implementation.

\section{References}

Dipiro JT, Talbert RL, Yee GC, Matzke GR, Wells BG, and Posey LM. (2017). Pharmacotherapy a pathophysiologic approach, $10^{\text {th }}$ ed New York: McGraw Hill. 45-78.

Elisa. N. (2019). Antihypertensive activity test of extracts and leaf fractions of matoa (Pometia pinnata JR Forster \& JG. Forster) in male rats induced by angiotensin II using blood pressure parameters and cardiac muscle cell image.

Kumar et al. (2014). Enthancement of solubility and disolution rate of irbesartan by solid dispersion thechnique. Journal of Pharmaceutical and Clinical Research (9), 0974-2441. 
Larson AJ, Symons JD, Jalili T. (2010). Quercetin: A treatment for hypertension. Pharmaceuticals,; 3(1), 237-250. https://doi.org/10.3390/ph3010237

Park SE et al. (2014). Induction of apoptosis in MDA-MB human breast carcinoma cells with an ethanol extract of cyperus rotundus L. by activating caspases: 5-6 https://doi.org/10.3892/or.2014.3507

Purwidyaningrum I, Sukandar EY, Fidrianny. (2017). Antihypertensive activity of extract and fractions of matoa (Pometia pinnata J. R \& G Forts) Leaves. Asian J Pharm Clin Res, 10(3), 323-328. https://doi.org/10.22159/ajpcr.2017.v10i3.16221

Riskesda. (2018) Health Research and Development Agency, Ministry of Basic Health, 88-94

Suedee A, Tewtrakul S, and Panichayupakaranant P. (2013). Anti-HIV-1 integrase compound from Pometia pinnata leaves, Pharmaceutical Biology, 51(10), 12561261. https://doi.org/10.3109/13880209.2013.786098 World Health Organization. (2012). Managing for Rational Medicine Use. Geneva 